\title{
Tethered Cord Syndrome in Adults: Experience of 56 Patients
}

\section{Erişkinlerde Gergin Omurilik Sendromu: 56 Hastallk Deneyim}

\author{
Mehmet SELCUKI ${ }^{1}$, Mesut METE ${ }^{1}$, Mustafa BARUTCUOGLU ${ }^{1}$, Yusuf Kurtulus DURANSOY ${ }^{1}$, \\ Ahmet Sukru UMUR ${ }^{1}$, Deniz SELCUKI ${ }^{2}$ \\ ${ }^{1}$ Celal Bayar University, School of Medicine, Department of Neurosurgery, Manisa, Turkey \\ ${ }^{2}$ Celal Bayar University, School of Medicine, Department of Neurology, Manisa, Turkey
}

Corresponding Author: Mesut METE / E-mail: dr.mmete@hotmail.com

\begin{abstract}
AIM: The aim of this study was to describe the results of surgery performed in a group of adult patients with tethered cord syndrome with their outcomes.

MATERIAL and METHODS: This retrospective study included 56 patients. There were 38 females and 18 males. All patients were older than 18 years.

RESULTS: The mean age at referral was 36 years and 1 month. The mean follow-up period was 10 months 27 days. $95 \%$ of all patients with back and leg pains improved and 5\% remained the same. Three patients with motor deficits remained the same in the postoperative period. Of the 16 patients with urological complaints, 10 improved, 5 unchanged and 1 patient died in the postoperative first day due to pulmonary embolism.

CONCLUSION: The syndrome of tethered cord may be a situation to be treated even in the elderly in case of normal level conus medullaris and filum terminale with a normal appearance as well as a low-lying conus and thick filum. To prevent overlooking the diagnosis of tethered cord and/or unnecessary spinal surgeries, the tethered cord syndrome should be remembered in the differential diagnosis list in the presence of back and leg pains, neurological deficits or urological complaints.
\end{abstract}

KEYWORDS: Tethered cord syndrome, Adult, Filum terminale, Urodynamic study

öz

AMAÇ: Çalışmada; gergin omurilik sendromu olan erişkin hastalarda yapılan cerrahi tedavinin sonuçları sunulmuştur.

YÖNTEM ve GEREÇLER: Bu retrospektif çalışma 56 hasta içermektedir. Hastaların 38'i kadın, 18'i erkek olup tüm hastalar 18 yaşından büyüktür. BULGULAR: Ortalama yaş 36 yıl 1 ay idi. Ortalama takip süresi 10 ay 27 gündü. Bel-bacak ağrısı olan hastaların \%95'inde postoperatif dönemde şikayetlerinde düzelme olurken \% 5 'inde düzelme olmadı. Motor defisiti olan 3 hastada postoperatif dönemde düzelme olmadı. Ürolojik şikayeti olan 16 hastanın, 10'unda postoperatif dönemde düzelme olurken $5^{\prime}$ inde şikayetler devam etti. Bir hasta postoperatif 1 . günde pulmoner emboli nedeniyle kaybedildi.

SONUÇ: Gergin omurilik sendromu; hem düşük seviyeli konus medullaris ve kalın filum terminale hem de normal görünümlü konus medullaris ve filum terminale şeklinde olabilir ve yaşlı hastalarda tedavi edilebilir bir durumdur. Gergin omurilik sendromunun gözden kaçmasını ve gereksiz spinal cerrahileri engelleyebilmek için, bel ve bacak ağrısı, nörolojik defisit ve ürolojik şikayet varlığında ayırıcı tanıda akılda tutulmalıdır.

ANAHTAR SÖZCÜKLER: Gergin omurilik sendromu, Erişkin, Filum terminale, Ürodinamik çalışma

\section{INTRODUCTION}

Tethered cord is a "syndrome" that has a spectrum of neurological, urological or orthopedic symptoms and findings related to the malformations of the spinal cord. Many underlying causes of tethered cord have been reported previously $(1,3-10,13,16)$. The filum terminale should be elastic. Disturbance of the viscoelasticity of the filum terminale causes transfer of tension to the conus medullaris and symptoms occur $(10,12,14)$. Although symptoms mostly occur in childhood, they are also not uncommon in adults. Pain is the most common symptom. Motor weakness, stool and urinary incontinence can also be seen $(1,4,7,9,16)$ and the manner of treatment in adults is still controversial $(1,5,9)$. The aim of this study was to present the results of surgery performed in a group of adult patients with the tethered cord syndrome with their outcomes.

\section{MATERIAL and METHODS}

This retrospective study included 56 patients who were operated for tethered cord syndrome by one of authors in the Neurosurgery Department of Celal Bayar University School of Medicine from 1994 to 2013. Local ethics committee approval (No: 20478486-24) was obtained from Celal Bayar University School of Medicine. There were 38 females and 18 males. All patients were older than 18 years old. Four patients who refused surgery were excluded from this study. 


\section{RESULTS}

Epidemiological data, clinical charts, imaging and surgical observation and follow-up data were reviewed for each patient. The ages of the patients ranged from 19 years to 74 years and the mean age at referral was 36 years and 1 month. The mean follow-up period was 10 months 27 days (range 1 day to 12 years). Each patient underwent detailed neurological and radiological examination to determine causes of tethered cord syndrome. Most patients presented with back-leg pain or urological complaints, as stated by 40 (71\%) and 16 (28.5\%) patients respectively (Table I). Cutaneous findings, motor weakness, scoliosis, sensory deficits and reflex changes were evaluated on clinical examination (Table I). Eighteen patients (32\%) had cutaneous findings. A dimple and scar tissue were the most frequently seen cutaneous findings with 5 patients (Table I). Scar tissue was secondary to previous operations (lipomyelomeningocele in 1 patient, myelomeningocele plus epidermoid tumor in 1 patient, only myelomeningocele in 1 patient, and 2 patients operated for lumbar degenerative disease. Patients with lumbar degenerative disease and myelomeningocele plus epidermoid tumor were operated previously in another neurosurgery department).

Deep tendon reflex (DTR) changes and sensory changes were detected in 6 and 4 patients respectively. Scoliosis and motor weakness were detected in 4 and 3 patients respectively. Low-lying conus and fatty filum terminale were found on magnetic resonance imaging (MRI) in $15(27 \%)$ and $9(16 \%)$ patients respectively. The conus level was normal in 14 (25\%) patients (Table I). Urodynamic studies were performed in
16 patients who had urological complaints among the 56 patients. Neurogenic bladder was detected in 9 (56.25\%) patients. Hydronephrosis and detrusor sphincter dyssynergia were each detected in 1 (6\%) patient (Table I). Urodynamic studies were performed on the patients who had sphincter dysfunction or urological complaints such as urinary incontinence at first admission. All patients were evaluated with spinal somatosensory evoked potentials (SSSEPs) and a conduction block was detected in 35 (62.5\%) patients. SSSEPs were performed in patients in whom no bladder dysfunction was declared but symptoms of pain and/or scoliosis were present and we noted that results of SSSEPs examinations were helpful in the diagnosis of tethered cord syndrome.

All patients were operated under the operating microscope and the untethering procedure was applied to each patient. During surgery in patients with tethered cord secondary to various developmental lesions such as dermal sinus, lipoma and previous surgery (myelomeningocele, lipomyelomeningocele repair), maximum effort was made to release the spinal cord as much as possible from surrounding tissues with sharp dissection (Figure 1A-E). In patients with split cord malformation, the bony septum and the dural sheath of the bony spur were removed, the aberrant nerve roots and mesenchymal tissues on the medial surface of both hemicords were dissected, and the accessory and real filum terminale were cut (Figure 2A-E). In other patients such as those with a fatty filum terminale, thick filum terminale or normal thickness filum terminale with normal conus level, the fila terminalia were cut (Figures $3 A, B ; 4 A-C$ ). An intraoperative
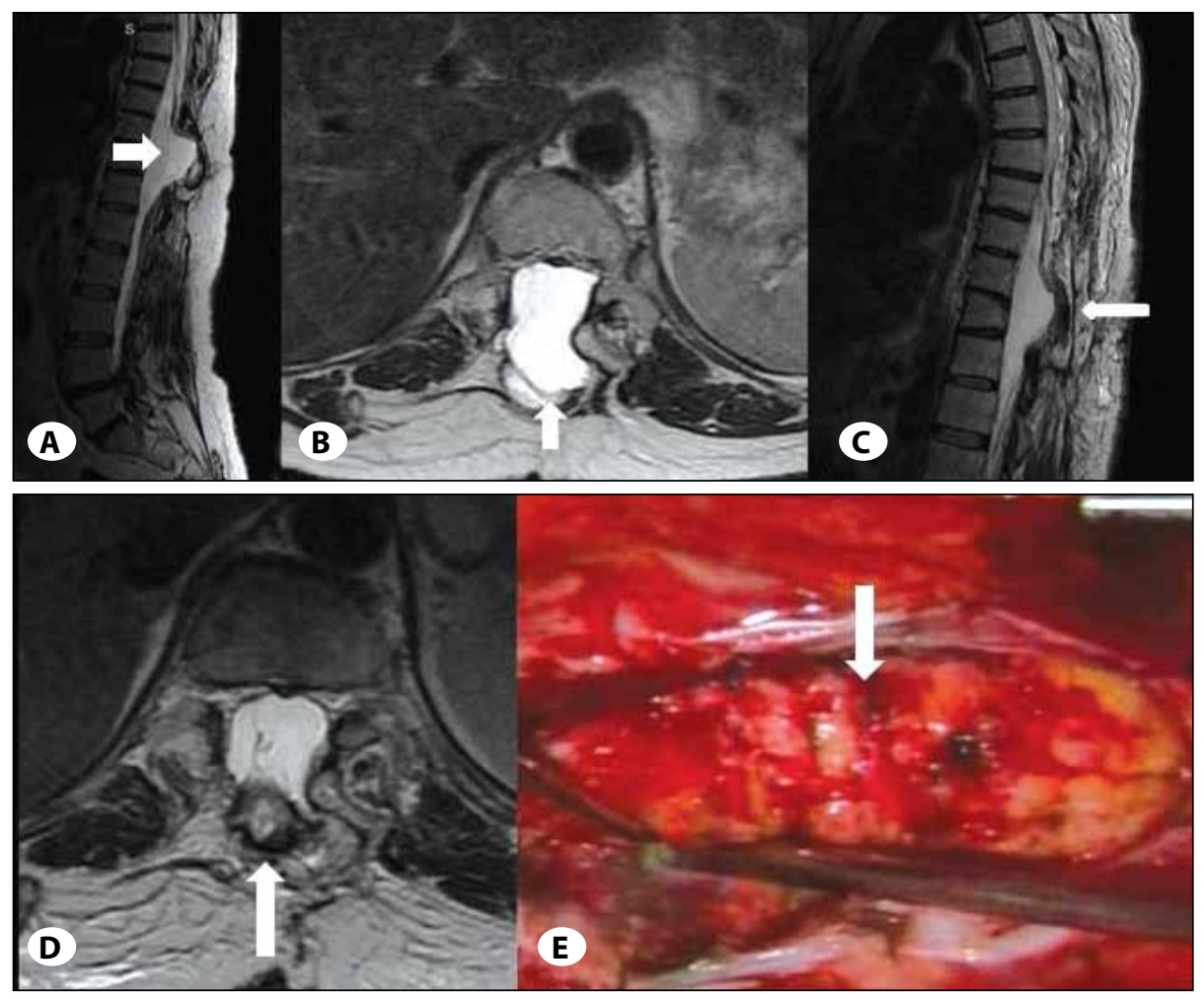

Figure 1: A- B) On sagittal and axial thoracolumbar MRI, the white arrow shows lipoma. C-D) Postoperative sagittal and axial MRIs demonstrate partial resection of lipoma.

E) Intraoperative photograph shows lipoma (white arrow). 
Table I: Patients' Parameters

\begin{tabular}{|c|c|}
\hline & Number of patients frequency (\%) \\
\hline Number of patients & 56 \\
\hline $\mathrm{M} / \mathrm{F}$ & $18 / 38$ \\
\hline Mean age at referral & $36 y 1 \mathrm{mo}$ \\
\hline Age range & \\
\hline $18-50$ years & $48(85.6 \%)$ \\
\hline $51-60$ years & $5(8.9 \%)$ \\
\hline $61-70$ years & $2(3.5 \%)$ \\
\hline 71 years $\leq$ & $1(1.7)$ \\
\hline Follow up period & 10mo 27 days \\
\hline Main reasons for Presentation & \\
\hline Back-Leg pain & $40(71 \%)$ \\
\hline Urological complaints & $16(28.5 \%)$ \\
\hline Skin abnormality & $5(9 \%)$ \\
\hline Orthopedic abnormality & $3(5 \%)$ \\
\hline Numbness-Contraction & $7(13 \%)$ \\
\hline Leg weakness & $3(5 \%)$ \\
\hline Neck-arm pain & $1(2 \%)$ \\
\hline Clinical Examination & \\
\hline Cutaneous findings & $18(32 \%)$ \\
\hline Dimple & $5(9 \%)$ \\
\hline Scar tissue & $5(9 \%)$ \\
\hline Hypertrichosis & $4(7 \%)$ \\
\hline Lipoma & $2(3.5 \%)$ \\
\hline Telengiectasia & $1(2 \%)$ \\
\hline Discharge & $1(2 \%)$ \\
\hline Motor weakness & $3(5 \%)$ \\
\hline Sensory deficitis & $4(7 \%)$ \\
\hline Scoliosis & $4(7 \%)$ \\
\hline Reflex change & $6(11 \%)$ \\
\hline Normal & $36(64 \%)$ \\
\hline MRI Findings & \\
\hline Low-Lying Conus & $15(27 \%)$ \\
\hline Fatty filum terminale & $9(16 \%)$ \\
\hline Thick filum terminale & $5(9 \%)$ \\
\hline Thicky fatty filum terminale & $5(9 \%)$ \\
\hline Syringomyelia & $6(11 \%)$ \\
\hline * Lumbar degenerative disease & $5(9 \%)$ \\
\hline Lumbar disc herniation & $3(5 \%)$ \\
\hline Lumbar stenosis & $2(3.5 \%)$ \\
\hline Split cord malformation type I & $3(5 \%)$ \\
\hline Dermal Sinus tract & $4(7 \%)$ \\
\hline Lipoma & $4(7 \%)$ \\
\hline Seconder to Myelomeningocele repair & $3(5 \%)$ \\
\hline Chiari malformation type I & $3(5 \%)$ \\
\hline Sacral agenesis & $2(3.5 \%)$ \\
\hline Vertebra defect (schisis) & $2(3.5 \%)$ \\
\hline Meningocele manqué & $1(2 \%)$ \\
\hline Arachnoid cyst & $1(2 \%)$ \\
\hline Epidermoid tumor & $1(2 \%)$ \\
\hline Normal & $14(25 \%)$ \\
\hline Urodynamic studies (for 16 patients) & \\
\hline Neurogenic bladder & $9(56.25 \%)$ \\
\hline Hydronephrosis & $1(6 \%)$ \\
\hline Detrusor sphincter dyssynergia & $1(6 \%)$ \\
\hline $\mathrm{N} / \mathrm{A}$ & $5(31 \%)$ \\
\hline Somatosensory spinal evoked potentials (SSEPS) & \\
\hline Block & $35(62.5 \%)$ \\
\hline Delay & $6(10.7 \%)$ \\
\hline Normal & $15(26.7 \%)$ \\
\hline
\end{tabular}

NA: Patients did not allow for urodynamic studies. 
neurostimulator was used to identify the roots that had to be preserved. At the end of the surgery, meticulous hemostasis was done. In addition, duraplasty was performed when required to enlarge the subarachnoid space in order to avoid re-tethering of spinal cord.

In the postoperative period, 2 patients suffered from headache secondary to cerebrospinal fluid leakage and cerebrospinal fluid fistula was controlled with resting in the prone position. Three patients with motor deficits remained the same in the postoperative period. All these 3 patients had been pre- viously operated for the repair of myelomeningocele-lipomyelomeningocele. One patient died on the postoperative first day due to pulmonary embolism.

We found that 38 (95\%) of the 40 patients with back-leg pain improved and 2 (5\%) remained the same. Of the 16 patients with urological complaints, 10 (62.5\%) improved, 5 (31\%) were unchanged and 1 patient died on the postoperative first day.

More detailed analysis was done for younger and older patients. Namely, we had 8 patients older than 50 years.
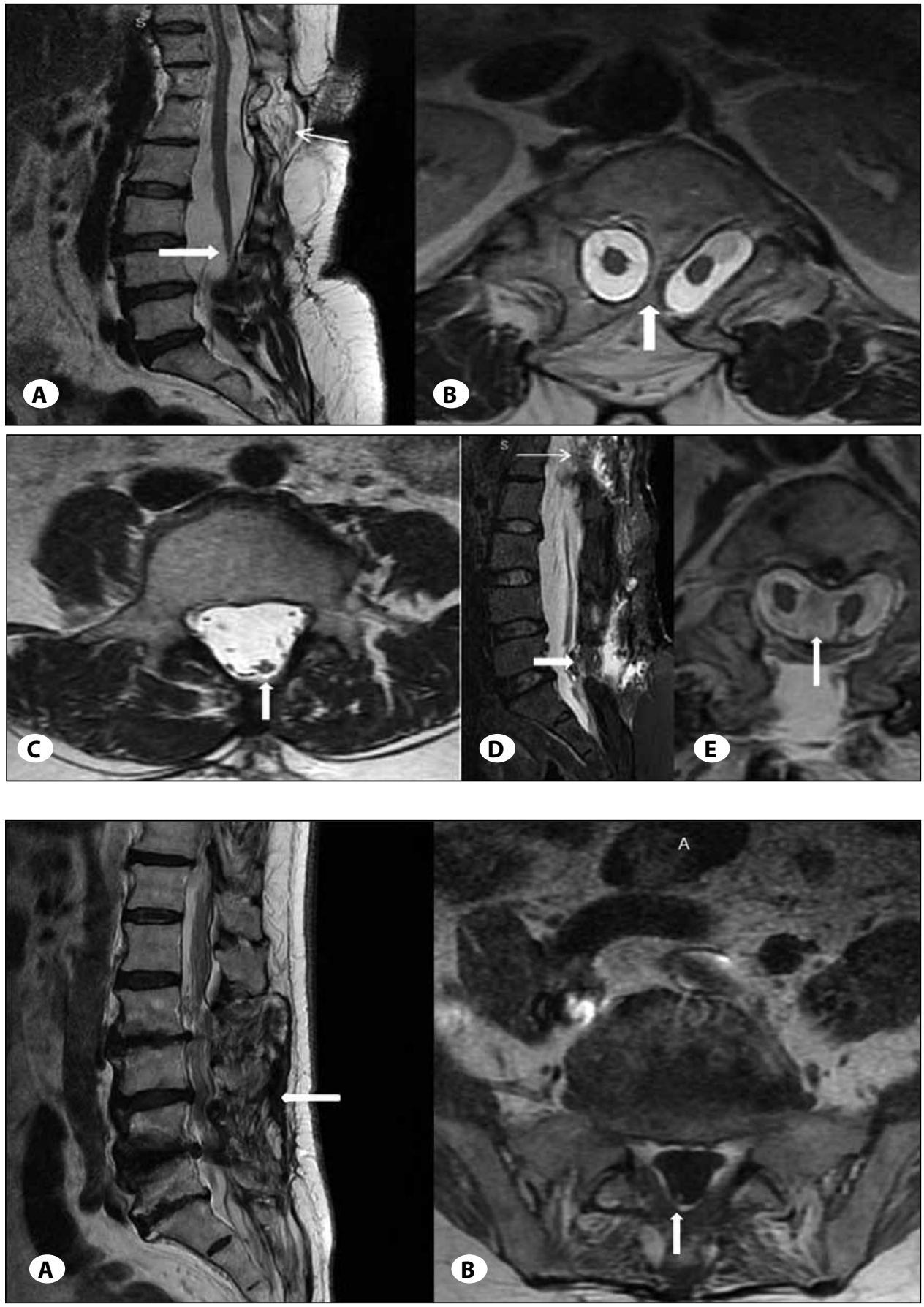

Figure 2: A) On sagittal MRI, the thick white arrow shows attachment point of the thick filum and the thin white arrow shows the bone septum at the thoracolumbar level.

B) On axial MRI, the white arrow shows bone septum which splits the spinal cord into two hemicords and have their own dura mater. C) On axial MRI, the white arrow shows a thick filum terminale.

D, E) Postoperative sagittal and axial MRIs demonstrate complete resection of bony septum and lumbar left hemilaminectomy (thin and thick white arrows).

Figure 3: A) On sagittal lumbar $M R I$, the white arrow shows postoperative changes. B) On axial T1-weighted lumbar MRI, the white arrow shows hyper-intense fatty thick filum terminale. 
Detailed characteristics for older patients are given in Table II. Mean follow-up time was 19 months (range 3 months to 36 months). While all these patients had back-leg pain ( 2 of the 8 had been operated for lumbar degenerative disease previously), 1 of the 8 additionally had urinary incontinence. In the postoperative period, improvement of back-leg pain was seen in $87.5 \%$. The patient with urinary incontinence reported improvement in his bladder dysfunction in the postoperative period. However, in younger patients ( $<50$ years old), 31 (96.8\%) of 32 patients with back-leg pain improved and 1 remained the same. Of the 15 patients with urological complaints, 9 (15\%) had improved, 5 (33.3\%) were unchanged and the remaining patient died on the postoperative first day. When we compared the younger and older patients for etiology, we found that a low-lying conus and normal thickness filum terminale with a normal level (NTFT-NL) was present in $14(29.1 \%)$ and 12 (25\%) patients respectively in the younger patient group. On the other hand, the most common underlying pathology in older patients was a fatty thicker filum terminale with $3(37.5 \%)$ patients, followed by fatty filum terminale and NTFT-NL with 2 (25\%) patients for each (Table II).

Another detailed analysis was done for tethered cord patients with normal MRI. We found that 14 of the 56 adult patients with tethered cord had filum terminale with normal thickness and with normal level conus medullaris on MRI (accompanying pathologies such as fatty filum terminale, thicker filum terminale, split cord malformation, lipoma, lumbar degenerative disease, secondary to myelomeningocele, lipomyelomeningocele repair etc. were excluded). Mean follow up period was 3 months and 21 days (range from 3 days to 15 months). While 8 of 14 had only sciatalgia, 2 of 14 had only urological complaints and both complaints were detected in 2 patients. The remaining patient had leg numbness and an orthopedic abnormality (scoliosis). We performed SSSEPs to all patients. While 11 of 14 had blockade, 2 of 14 had de-

Table II: Characteristics of Patients Older than 50 Years

\begin{tabular}{|c|c|c|c|c|c|c|c|}
$\begin{array}{c}\text { Number of } \\
\text { patients }\end{array}$ & $\begin{array}{c}\text { Age } \\
\text { (years) }\end{array}$ & Gender & $\begin{array}{c}\text { Main reason for } \\
\text { presentation }\end{array}$ & SSSEP & MRI & $\begin{array}{c}\text { Follow up } \\
\text { period }\end{array}$ \\
\hline 1 & 59 & M & Back-leg pain & Blockade & NLCM-NTFT & Improvement & $36 \mathrm{~m}$ \\
\hline 2 & 74 & M & Back-leg pain & Blockade & LS+FTFT & Improvement & $36 \mathrm{~m}$ \\
\hline 3 & 56 & $\mathrm{M}$ & Leg pain & Blockade & FTFT & Improvement & $24 \mathrm{~m}$ \\
\hline 4 & 51 & $\mathrm{M}$ & Back-leg pain & Delay & FFT & Improvement & $20 \mathrm{~m}$ \\
\hline 5 & 68 & $\mathrm{~F}$ & Back-leg pain+ & Blockade & LLCM+FTFT & Improvement & $12 \mathrm{~m}$ \\
\hline 6 & 53 & $\mathrm{~F}$ & Back-leg pain & Blockade & Lipoma & Unchanged & $18 \mathrm{~m}$ \\
\hline 7 & 63 & $\mathrm{M}$ & Back-leg pain & Blockade & FFT+LS & Improvement & $3 \mathrm{~m}$ \\
\hline 8 & 51 & $\mathrm{~F}$ & $\begin{array}{c}\text { Back-leg-neck and } \\
\text { arm pain }\end{array}$ & Blockade & Chiari I+ & Improvement \\
\hline
\end{tabular}

NLCM: Normal level conus medullaris, NTFT: Normal thickness filum terminale, LS: Lumbal stenosis, FFT: Fatty filum terminale, FTFT: Fatty thickness filum terminale, LLCM: Low-lying conus medullaris, m: months.
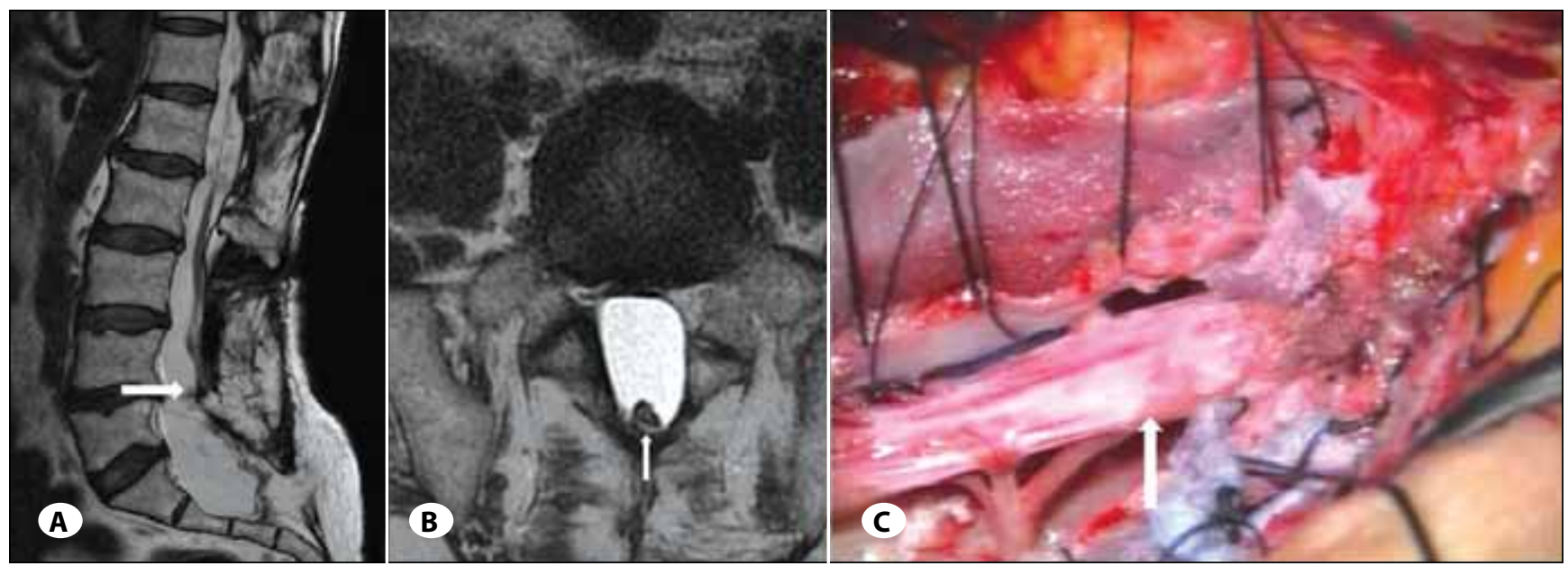

Figure 4: A) On sagittal lumbar MRI, the white arrow shows the attachment point of filum terminale B) On axial MRI, the white arrow shows a thick filum terminale. C) Intraoperative photograph shows a thick fatty filum terminale (white arrow). This appearance of thick filum has been named "retained medullary cord" by Dr. Pang. 
layed and the remaining patient had normal SSSEP. In the postoperative period, patients with sciatalgia and urological complaints reported improvement. However, patients with numbness and scoliosis complaints were unchanged.

\section{ILLUSTRATIVE CASES}

Case-1: This 41-year-old female presented with back-leg pain, leg weakness and urological complaints (for 10 years). In her history, she had been operated for lipomyelomeningocele 10 years ago. On her neurological examination she had right lower extremity paresis. She did not consent to urodynamic studies. During surgery under the operation microscope, partial lipoma resection was performed and the spinal cord released as much as possible from the surrounding tissue with sharp dissection. At postoperative 6 months, the paresis remained the same and she used clean intermittent catheterization for her urological complaints (Figure 1A-E).

Case-2: This 47-year-old female presented with complaints of back-leg pain and urinary incontinence that had started 2 years earlier. Her neurological examination was normal. During surgery, two different incisions were made. Under the operation microscope, the bony septum was removed and then the thick fatty filum terminale was cut after left hemilaminectomy. She died on the postoperative $1^{\text {th }}$ day due to pulmonary embolism during her first couple of steps of the first mobilization (Figure 2A-E).

Case-3: This 74-year-old male patient presented with backleg pain. His neurological examination was normal. The history revealed that he had suffered from back-leg pain for 12 years and had undergone an operation for lumbar stenosis 6 years ago. However, no improvement was noted in his complaints so far. We detected fatty filum terminale on MRI. During surgery, the dura mater was opened and the fatty filum terminale was cut (Figure 3A, B).

Case-4: This 63-year-old male patient presented with backleg pain and urinary incontinence. The history revealed that he had undergone 3 operations in 1980, 1990 and 2008 (twice for lumbar disc herniation and once for lumbar spinal stenosis respectively) but no improvement was noted in his complaints. In addition to the back-leg pain, urinary incontinence had started 5 months ago. He did not allow us to perform urodynamic studies but SSSEP revealed blockade of both lumbar and thoracic evoked waves. During surgery, under the operation microscope, thick filum terminale was cut (Figure 4A-C).

\section{DISCUSSION}

The tethered cord syndrome (TCS) is a clinical entity that arises from congenital anomalies and may cause craniocaudal traction of the spinal cord $(1,3,9,16)$. This traction causes reduction of spinal cord blood flow, leads to local tissue hypoxia that ends up with impaired mitochondrial oxidative metabolism, which can lead to cellular dysfunction and death of impaired cells $(9,13,16)$. Pang et al. (7) classified precipitating factors of TCS in 3 groups:
1- The momentary stretching of the conus (childbirth, strenuous exercise, forward bending, sexual intercourse). 2Narrowing of the spinal canal (lumbar stenosis, lumbar disc herniation, heavy lifting). 3- Trauma (fall on buttocks). The degree of tethering in adult patients is not enough to cause symptoms alone, but repetitive movements increase the tension on the spinal cord and eventually lead to symptoms $(3,9)$. After experimental studies, Yamada et al. reported that appearance of signs and symptoms of the tethered cord syndrome correlate with the severity of the tethering effect (16).

In adults, the main reasons for admission are back-leg pain, genito-rectal pain, sensory and motor deficits, cutaneous stigmata, scoliosis, lordosis, reflex changes, musculo-skeletal deformities, incontinence and disturbance of the anal sphincter $(1,3,4,5,9)$. Iskandar et al. reported that both pain and motor or sensory symptoms were the most common presentation complaints in their study with $79 \%$. In the same study, the bowel or bladder dysfunction rate was 53\% (4). In a study with 27 patients, Romagna et al. reported that lower back pain, radicular pain, motor deficits and urinary deficits were seen in the preoperative period at $48 \%, 55 \%, 52 \%$ and $18.5 \%$ respectively (9). In a large series, Lee at el. reported muscular weakness, back pain and bladder dysfunction as the first three symptoms that were seen in 78\%, 73\% and $71 \%$ respectively in their study with 60 patients (6). In our study, the main reasons of presentation were back-leg pain with $71 \%$ followed by urological complaints with $28.5 \%$. Motor deficits were seen less in contrast to the literature with $5 \%$ (Table I) The association of tethered cord with other pathological conditions such as myelomeningocele, lipomyelomeningocele, tumor, dermal sinus, bone or fibrous spicule, and/or fatty filum terminale have been reported (1, $4,5,6,7,9,16)$. Lee et al. found tight filum terminale in 17 of 60 patients and lipoma plus tight filum terminale in 11 of 60 patients (6). Rajpal et al., in a study with 61 patients, reported lipomyelomeningocele, tight filum terminale and split cord malformations in 25, 22 and 15 patients respectively (8). We noted low-lying conus and tight filum terminale on MRI in 15 and 9 patients respectively. Another accompanying pathology with tethered cord is terminal syringomyelia. Terminal syringomyelia is most often associated with tethered cord with a prevalence of $22.5-53 \%$ (2). Erkan et al. reported 30 terminal syringomyelia pediatric patients who had tethered cord. In our series, 6 of 56 patients had syringomyelia (2). While 3 of these 6 patients had cervical syringomyelia, 2 of the 6 had thoracic syringomyelia and the remaining patient had cervico-thoracic syringomyelia. In the follow-up period, MRI demonstrated syrinx regression in 4 of the 6 patients. One patient's syrinx was unchanged and the remaining patient was lost to our follow-up.

In the postoperative period, Lee et al. reported improvement of back and leg pains in $78 \%$ and $83 \%$ respectively. Improvement of motor deficits and urological dysfunction were seen in $64 \%$ and $50 \%$ respectively (6). Rajpal et al. reported lower rates of success in their study. The authors found improvement 
of back pain, leg pain and motor weakness in $65 \%, 53 \%$ and $47 \%$ respectively. Improvement of bowel and/or bladder dysfunction was seen in $62 \%$ (8). In our study, 38 (95\%) patients improved and $2(5 \%)$ remained the same within the group of 40 patients with back-leg pain. Three patients with motor deficits remained the same in the postoperative period. Of the 16 patients with urological complaints, $10(62.5 \%)$ had improved, 5 (31\%) were unchanged and one patient died on the postoperative first day due to pulmonary embolism. One of the important issue one needs to focus on is the outcome in older patients as this is not clear in the literature. In our 8 patients older than 50 years, all had back-leg pain ( 2 of 8 had been operated previously for lumbar degenerative disease) and one had urinary incontinence for 5 months. In the postoperative period, the pain was resolved in 7 of 8 patients. The patient with urinary incontinence reported improvement in his bladder dysfunction on the $3^{\text {rd }}$ month of the postoperative period (Table II). The high success rate of our clinical series in adults may be due to the same surgical team performing a large number of surgical procedures. Also, the suspicion for the possibility of tethered cord syndrome in the presence of normal MRI studies in a particular patient with low back pain and/or sciatalgia, in whom we performed SSSEP, may be the other important factor.

$\mathrm{MRI}$ is the best imaging technique for the diagnosis of a tethered cord if there is a low-lying conus or thick filum terminale $(1,16)$. Yamada et al. reported the MRI findings in the presence of a tethered cord. These are; 1- Thicker filum terminale ( $>2 \mathrm{~mm}$ diameter). 2- An elongated spinal cord 3- Posterior displacement of the conus medullaris and filum terminale. A wide sacral subarachnoid space is also not uncommon (16). One of the most important points is whether these pathological findings are seen every time on MRI. Although the diagnosis of a tethered cord with a low-lying conus medullaris and thicker filum terminale (more than $2 \mathrm{~mm}$ diameter) is easy, Selcuki et al. reported that normal thickness of filum terminale with normal level conus medullaris may still have a tethering effect if the filum terminale's internal structure is not normal (12). The same authors treated 10 children with normal level conus medullaris and with normal thickness filum terminale (10). Tu et al. reported in a literature review that $14-28 \%$ of patients with tethered cord had normal level conus medullaris on MRI (14). In our study, 14 of 56 patients had normal level conus medullaris with normal thickness on MRI. In patients with normal MRI findings, urodynamic studies (if the patient has urological complaints) or SSSEPs (patients with pain or scoliosis in particular) should be performed to support the diagnosis of tethered cord syndrome. Selcuki et al. reported that SSSEP results were abnormal in 4 of 17 patients $(24 \%)$ who had tethered cord with normal level conus medullaris and normal thickness filum terminale (11). We performed SSSEPs in all patients with normal level conus medullaris and normal thickness filum terminale. We found that 11 of the 14 had a blockade, 2 of 14 were delayed and the remaining patient had normal SSSEP.

Another important point is that a tethered cord can be overlooked in the presence of additional pathology such as lumbar disc herniation, lumbar spinal stenosis or lumbar spondylolisthesis on MRI (Figure $3 \mathrm{~A}, \mathrm{~B} ; 4 \mathrm{~A}-\mathrm{C}$ ). It has already been reported that tethered cord symptoms can mimic lumbar degenerative disease symptoms $(3,15)$. In our study, 2 of 56 patients had been operated for lumbar degenerative disease previously at other hospitals (Figures $3 A, B ; 4 A-C$ ). One was a 74-year-old male patient who presented with back-leg pain. His neurological examination was normal. The history revealed that he had suffered from back-leg pain for 12 years and underwent surgery for lumbar stenosis 6 years ago but no improvement was noted in his complaints so far. We determined fatty filum terminale on MRI. During surgery, the dura mater was opened and the fatty filum terminale was cut (Figure 3A,B). Another patient was a 63-year-old male patient who presented with back-leg pain and urinary incontinence. His hitory revealed that he had undergone 3 operations in 1980, 1990 and 2008 (twice for lumbar disc herniation and once for lumbar spinal stenosis respectively) but no improvement was noted in his complaints either. In addition to back-leg pain, urinary incontinence had started 5 months ago. He did not allow us to do a urodynamic study but SSSEP revealed blockade of both lumbar and thoracic evoked waves. During surgery under the operation microscope, the thick filum terminale was cut (Figure 4A-C). Both patients' complaints were resolved in the postoperative period. These 2 patients and the reported cases in literature (15) show that lumbar degenerative disease may cause unnecessary spinal surgeries in adult patients, in the presence of back/leg pain. In case of such patients and especially with normal or conflicting MRI results, tethered spinal cord should come to mind at least as an important possibility in the differential diagnosis. Three of the 56 patients in our series had both tethered cord and lumbar degenerative disease findings on MRI (Table I) and during surgery, we cut the filum terminale and treated the degenerative disease with hemipartial laminectomy plus discectomy.

Standard management for adult tethered cord is still controversial. Some authors suggest prophylactic surgery before neurological deterioration $(1,6,7,8)$ while some authors recommend surgery in symptomatic patients only $(5,9)$. Patients frequently ignore surgery for complication risk and prefer delayed surgery until severe pain and/or the development of new symptoms are realized. However we know that neurological deficits, (urinary incontinence in particular, which is extremely difficult to overcome) and orthopedic deformities appear with advanced age and an active life $(1,8)$. For this reason, we suggest early surgery in newly diagnosed adult patients (symptomatic or asymptomatic), after the possible complication risks and benefits of the operation have been explained.

\section{CONCLUSION}

1- The syndrome of tethered cord may need to be treated even in the elderly in case of normal level conus medullaris and filum terminale with normal appearance as well as a low-lying conus and thick filum. It should not be forgotten 
that the intensity of the tethering effect determines the timing of the arrival of the symptoms, despite the type and variety of the malformation that caused the tethered cord. The less the tethering effect the more the time needed for the symptoms to appear.

2- To prevent overlooking the diagnosis of tethered cord and/or unnecessary spinal surgeries, the tethered cord syndrome should be remembered in the differential diagnosis list in the presence of back-leg pain, neurological deficits or urological complaints. The possibility of tethered cord syndrome must be kept in mind especially in case of normal MRI studies in a patient with low back pain and/or sciatalgia. In order to exclude or diagnose the tethered cord syndrome, additional investigations such as somatosensory spinal evoked potentials and/or urodynamic studies should be done.

3- Even in the presence of degenerative disease findings (such as lumbar disc herniation or lumbar stenosis) on MRI, the MRI should be evaluated thoroughly for fatty or thick filum for the possible association of tethered cord syndrome, as a tethered spinal cord is more frequent than expected.

4- After a definitive diagnosis of the tethered cord syndrome has been made, surgical treatment should be administered as soon as possible, even as a prophylactic measure to prevent the appearance of new symptoms such as neurological deficits and/or bowel-bladder dysfunction.

\section{REFERENCES}

1. Akay KM, Ersahin Y, Cakir Y:Tethered cord syndrome in adults. Acta Neurochir (Wien)142(10):1111-1115,2000

2. Erkan K, Unal F, Kiris T, Karalar T: Treatment of terminal syringomyelia in association with tethered cord syndrome: Clinical outcomes with and without syrinx drainage. Neurosurg Focus 8(3):E9, 2000

3. Hertzler DA 2nd, De Powell JJ, Stevenson CB, Mangano FT: Tethered cord syndrome: $A$ review of the literature from embryology to adult presentation. Neurosurg Focus 29(1):E1, 2010
4. Iskandar BJ, Fulmer BB, Hadley MN, Oakes WJ: Congenital tethered spinal cord syndrome in adults. Neurosurg Focus 10(1):e7,2001

5. Klekamp J: Tethered cord syndrome in adults. J Neurosurg Spine 15(3):258-270,2011

6. Lee GY, Paradiso G, Tator CH, Gentili F, Massicotte EM, Fehlings MG: Surgical management of tethered cord syndrome in adults: Indications, techniques, and long-term outcomes in 60 patients. J Neurosurg Spine 4(2):123-131,2006

7. Pang $D$, Wilberger JE Jr: Tethered cord syndrome in adults. J Neurosurg 57(1):32-47,1982

8. Rajpal S, Tubbs RS, George T, Oakes WJ, Fuchs HE, Hadley MN, Iskandar BJ: Tethered cord due to spina bifida occulta presenting in adulthood: A tricenter review of 61 patients. J Neurosurg Spine 6(3):210-215,2007

9. Romagna A, Suchorska B, Schwartz C, Tonn JC, Zausinger S: Detethering of a congenital tethered cord in adult patients: An outcome analysis. Acta Neurochir (Wien) 155(5):793-800, 2013

10. Selcuki M, Coskun K: Management of tight filum terminale syndrome with special emphasis on normal level conus medullaris (NLCM). Surg Neurol 50(4):318-322,1998

11. Selcuki M, Unlu A, Ugur HC, Soygur T, Arikan N, Selcuki $D$ : Patients with urinary incontinence often benefit from surgical detethering of tight filum terminale. Childs Nerv Syst 16(3):150-154,2000

12. Selcuki M, Vatansever S, Inan S, Erdemli E, Bagdatoglu C, Polat A: Is a filum terminale with a normal appearance really normal? Childs Nerv Syst 19(1):3-10,2003

13. Stetler WR Jr, Park P, Sullivan S: Pathophysiology of adult tethered cord syndrome: Review of the literature. Neurosurg Focus 29(1):E2,2010

14. Tu A, Steinbok P: Occult tethered cord syndrome: A review. Childs Nerv Syst 29(9):1635-1640,2013

15. Umur AS, Selcuki M, Selcuki D, Beduk A, Doganay L: Adult tethered cord syndrome mimicking lumbar disc disease. Childs Nerv Syst 24(7):841-844,2008

16. Yamada S, Lonser RR: Adult tethered cord syndrome. J Spinal Disord 13(4):319-323,2000 